\title{
A CONSOLIDAÇÃO E EFETIVAÇÃO DO APARATO LEGISLATIVO EM PORTUGAL E AS AÇÕES JURÍDICO- ADMINISTRATIVAS DE D. AFONSO IV PARA MINIMIZAR OS EFEITOS DA PESTE EM SEU GOVERNO
}

\author{
The consolidation and effectiveness of the legislative \\ apparatus in Portugal and the legal-administrative actions of \\ D. Afonso IV to minimize the effects of the plague in your \\ government
}

\author{
Profa. Dra. Cleusa Teixeira de Sousa ${ }^{1}$ \\ Docente de História da Faculdade de Inhumas - FacMais \\ Pesquisadora do CHSC-FLUC- \\ Universidade de Coimbra e Membro do Grupo de Pesquisas Sapientia. \\ ORCID: https://orcid.org/0000-0001-7252-9438 \\ E-mail: cleotsou@gmail.com
}

Recebido em: 13/09/2020

Aprovado em: 20/12/2020

\begin{abstract}
Resumo: O objetivo principal deste artigo, versa sobre a representatividade de D. Afonso IV na sistematização do aparato burocrático-administrativo do reino português, bem como em sua atuação efetiva quanto a promulgação de leis que visaram minimizar os efeitos devastadores da peste e, por conseguinte, da fome em Portugal a seu tempo. Visto que a administração levada a cabo por este monarca, conduziu-se em garantir a ordenação do reino. Lembrando que, a efetividade dos estudos jurídicos e dos aparatos legislativos foram propiciados pela implantação dos cursos de Direito na Universidade portuguesa desde sua fundação em 1290. Fatores, que contribuíram de modo sistemático para o desenvolvimento dos objetivos pautados na dinamização jurídica e na consolidação do corpus legislativo do governo afonsino.
\end{abstract}

Palavras-chave: D. Afonso IV; Peste; Legislação; Poder régio.

Abstract: The main objective of this article, is about the representativeness of D. Afonso IV in the systematization of the bureaucratic-administrative apparatus of the Portuguese kingdom, as well as in his effective performance in the enactment of laws that aimed to minimize the devastating effects of the plague and, for consequently, of the famine in Portugal in its time. Since the administration carried out by this monarch, he conducted himself in guaranteeing order in the kingdom. Recalling that, the effectiveness of legal studies and legislative apparatuses has been favored by the implementation of Law courses at the Portuguese University since its foundation in 1290. Factors, which have contributed in a systematic way to the development of the objectives guided in the legal dynamism and in the consolidation of the corpus afonsino government legislative.

Keywords: D. Afonso IV; Plague; Legislation; Regal power. 


\section{Considerações introdutórias}

D. Afonso IV foi uma figura emblemática, mesmo após ter se envolvido em diversas contendas com o seu genitor, se constituiu como o sétimo rei de Portugal. Filho da rainha D. Isabel (1282-1336) e de D. Dinis (1279-1325), seus avós maternos foram os reis de Aragão, Pedro III (1276-1285) e Constança de Hohenstaufen (1249-1302). Nascido aos 8 dias do mês de fevereiro de 1291, na cidade de Coimbra (JESUS, 2009: 6). Fora, o segundo filho de D. Isabel ${ }^{2}$ e D. Dinis, Afonso teve vários "meios-irmãos", provenientes dos relacionamentos extraconjugais do pai. Sua mãe, D. Isabel, recebeu o cognome de "Rainha Santa" quando foi canonizada ${ }^{3}$ pelo Vaticano em 1625 ou 1626 (pelo papa Urbano VIII), por conta de sua temperança, paciência e benevolência, visto que mesmo sabendo dos adultérios do marido, não se furtou em cuidar de seus filhos "bastardos" e educá-los.

Este monarca, assumiu o trono após o passamento de se pai D. Dinis em 1325. Logo que foi coroado, o novo rei buscou submeter o clero, a nobreza e o povo à sua autoridade. Para tanto, era fundamental que o novo monarca manifestasse seu poderio no reino, visto que, durante a administração dionisina, o território português passara por longos períodos de guerra civil, alguns conflitos incentivados por ele próprio, contra o seu senhor natural. Como já é sabido, D. Afonso IV enfrentou momentos delicados em seu reinado, logo ao assumir o trono português querelou com seus meio-irmãos por conta dos privilégios que seu pai havia lhes concedido ainda em vida. Acusou Afonso Sanches (1289-1329), o penalizando ao desterro perpétuo e lhe confiscando os seus bens. Procedeu da mesma maneira com seu outro irmão bastardo João Afonso, o acusando de traidor, imputou-lhe sentença de morte. Afonso Sanches revoltado com essa decisão a respeito de seu irmão João Afonso - que morreu degolado -, invadiu Portugal e decretou guerra à D. Afonso IV, o conflito só teve fim após a doença de Afonso Sanches que veio a falecer em 1329.

Entre os anos de 1336 e 1339 ocorreu nova contenda entre Portugal e Castela, D. Afonso IV atacou as terras fronteiriças a este reino, descontente com o modo como Afonso XI tratava sua filha D. Maria (1313-1357), a qual era destratada por seu marido. Conquanto, D. Afonso IV negociou o casamento de seu herdeiro o infante Pedro com a filha de Juan Manuel, rival de seu genro, descumprindo o acordo que outrora havia 
realizado com o rei de Castela, de que sua sobrinha D. Branca seria a futura rainha de Portugal. Essa guerra gerou inúmeras mortes, invasões, incêndios, pilhagens, massacres, prisões findando-se somente por meio da intervenção pontifícia (Bento XII, 13341342), de D. Maria e do rei francês (Filipe VI, 1328-1350), quando em julho de 1339, D. Afonso IV assinou-se o tratado de paz e Sevilha.

Após findado os conflitos desse evento, os reinos de Castela e Portugal selaram aliança, objetivando impedir o avanço dos mouros na tomada de Gibraltar e a entrada do rei de Marrocos na Península Ibérica aliando-se aos granadinos para prosseguir para o norte. Conforme Rui de Pina em Chronica d'el-rey D. Afonso IV o espírito de liderança e o ânimo com que o rei de Portugal enfrentou os exércitos sarracenos em território castelhano foi imprescindível para a vitória da batalha do Salado:

\footnotetext{
Pelo qual viendo elRey de Castilla, \& os grandes homens de seu conselho o voto, \& determinação de elRey de Portugal, que parecia favorecido da graça de Deos, \& que a sua contradiçam lhe fazia grande mingoa se a nam consentissem, tomarão loguo todos grãde esforço em seus coraçoes, \& sem mais alteraçam asentaraõ em suas vontades o Catholico, \& devoto, \& muy Real Conselho de elRey de Portugal, que era socorrer Tarifa, u \& non de negar, antes procurar batalha com os Reys Mouros q eraõ no serquo prezentes[...] (CHRONICA D’EL-REY D. AFONSO IV, 1653: 137).
}

A aliança foi importante para vitória da Batalha do Salado em outubro de 1340, a qual marcou o fim das esperanças islamitas em recuperar a Península Ibérica, para além do reino de Granada. Contudo, o envolvimento deste monarca nestas guerras demandou gastos exorbitantes para o reino. A situação veio a agravar-se com o surto da Peste que assolou supostamente um terço da população europeia.

Com a autoridade do monarca firmada e os ânimos apaziguados, a política estabelecida por D. Afonso IV assumiu duas vertentes: empenhou-se em firmar o poder e a autoridade, no interior do reino dirimindo quanto as questões que s fizessem necessárias para o bom andamento de seu governo - como ocorreu nos casos motivados pela peste -; estabeleceu negócios com o exterior, objetivando restabelecer a paz com os reinos vizinhos, usando da diplomacia para cuidar dos seus interesses.

A principal tarefa de D Afonso IV em seu reinado foi conferida à consolidação do poder jurídico português, pois seu pai lhe deixou por herança a administração de um 
reino em franca ascensão econômica e que não dependia dos aliados antigos (nobreza e clero) como ocorria nos primeiros reinados. Além de contar com o apoio do poder concelhio que neste período encontrava-se forte e composto por membros fiéis ao monarca, dispostos a contribuir em eventuais decisões. Sabe-se que as primeiras inquirições foram realizadas por Afonso II em 1220, as autoridades percorreram o norte do país procurando averiguar os bens e rendimentos da coroa e buscando evitar os abusos em extensão de terras e direitos em honras e coutos por parte da nobreza e do clero. Essas medidas de fato eram avançadas para a época, porém necessárias para a consolidação do reino e do poder régio.

A priori, era desejo de D. Afonso IV dominar a justiça. E assim, ele o fez, reforçando ao longo de seu reinado a teoria de que o poder vem de Deus, sem intermediários como a corrente hierocrática. E esse poder era dado aos monarcas para que regessem o povo no reto caminho. Buscou, assim, mostrar que a justiça era o maior bem e que esta pertencia ao monarca (COELHO, 1988: 40).

Aristóteles assinala na Política que a justiça é uma das principais virtudes para um bom governante/legislador. Abundante foi a legislação atribuída a D. Afonso IV. Principiada ou não nas cortes, o certo é que este monarca reestruturou os campos jurídico, administrativo, econômico, social e até moral em seus tempos de reinado. Rodeado de juristas e procurando assumir a parte jurídica do reino, D. Afonso IV organizou o tribunal das cortes e constituiu o corpo legislativo tendo em vista os variados matizes relacionados à função judicial, desde o modo de proceder nas audiências até as intervenções de advogados nos sistemas de provas e nas execuções de sentenças (HOMEM, 1985).

D. Afonso IV agiu de forma igualitária com o poder concelhio, buscando fortalecer o poder régio nessa circunscrição. Os reis anteriores criaram as comunidades concelhias rurais e urbanas, com fins variados, que iam desde o povoamento e defesa até a pacificação social. Podiam, ainda, ser voltados para os interesses financeiros, garantindo aos monarcas apoio para enfrentar seus aliados tradicionais (clero e nobreza). O monarca passou a nomear os corregedores para as comarcas, os quais tinham funções ampliadas, que consistiam em inspecionar a justiça e o zelo dos magistrados locais e funcionários régios. Também eram responsáveis por supervisionar a eleição dos oficiais, reconhecer as rendas municipais e lidar com vários outros 
problemas que pudessem ocorrer internamente, tais competências passaram a integrar o regimento de 1332 e, em 1340, foram ampliadas. Os juízes de fora ou juízes régios vieram posteriormente a fazer parte dos concelhos régios, pois, na visão de D. Afonso IV, eles eram conhecedores da ciência jurídica e compunham uma comunidade estranha, fato que garantia maior imparcialidade na execução da justiça (COELHO, 1988: 42).

Observa-se que, em meio a esse processo de afirmação régia, a administração interna dos municípios passou a exigir cada vez mais especialização dos governantes. Desta maneira, surgem os vereadores que, em conjunto com outros oficiais, acabaram formando a câmara, em meados do século XIV, instituindo-se como principal órgão governamental. Assim, os senhores perderam boa parte da jurisdição, ficando com as causas criminais em raríssimos casos e, em alguns outros, com os civis. Percebe-se que a partir de meados do século XIV, os oficiais, os corregedores e os juízes de fora se ocuparam em controlar a justiça do reino. D. Afonso IV, portanto, cumpriu seu objetivo de legislador supremo da justiça, por meio de seus ouvidores e sobrejuízes e, deste modo, superintendia através de seus delegados nos concelhos. Diante de tal poder, buscou reordenar e moralizar todo o corpo social e econômico do reino português.

\section{A concepção de poder para Afonso IV}

D. Afonso IV, baseando-se na ação iniciada por seu avô D. Afonso III, que estabeleceu um total de 233 atos legislativos, e continuada por seu filho e sucessor D. Dinis, que criou um número menor de leis se comparado ao seu genitor, totalizando 129. D. Afonso IV tornou a justiça atuante em Portugal (FERNANDES, 2004). Assessorado pelos órgãos competentes, principiou formas de execução jurídica, num processo de sistematização de normas de funcionamento do aparelho burocrático-administrativo, pautando seu reinado no princípio de ressurgimento dos estudos do direito romano propiciado pela criação e implementação do Sudium Generale em Portugal em 1290. Prosseguiu seu reinado comungando do mesmo objetivo de seu antecessor, com o fito de fortalecer o poder régio em detrimento do poder eclesiástico.

Ademais, a administração de D. Afonso IV trouxe alguma inovação em sua relação com o clero, pois ele investiu profundamente nos estudos jurídicos, cercando-se de juristas e de estudiosos do direito romano, visto que quando este rei assumiu o trono 
já havia pouco mais de meio século da fundação (1290) e exercício do curso de Direito na Universidade portuguesa. Este rei, movimentava-se constantemente pelo reino, realizando as cortes itinerantes e julgando as causas necessárias.

Deste modo, D. Afonso IV buscou consolidar seu objetivo principal em sua governança, o qual seja, ser juiz supremo do reino e instituir-se representativamente como "cabeça, coração e alma" do reino. Essa metáfora, é baseada na representação do poder simbólico e performático, em que a cabeça comanda o corpo, assemelhando-se a imagem do monarca que conduz o seu reino com eficácia; enquanto o coração é o órgão que garante a vitalidade humana, por bombear e enviar sangue para todas as partes ao corpo ativando seu perfeito funcionamento. Essa representação simbólica, aplicada a este contexto, tem a função de evidenciar a figura do rei, que caminha por todo seu reino e o administra com dinamismo. Já a representatividade da alma, neste contexto, está relacionada as forças motrizes, responsáveis por apaziguar e garantir espiritualidade ao corpo. Assim, essas características eram exploradas a esse tempo na tentativa de assimilar a figura deste monarca ao mais perfeito modo de governar. Tratava-se de um modo de demonstrar que D. Afonso IV, buscava amainar e reger da melhor forma todo seu senhorio. A esse respeito, as Ordenações de Dom Duarte e Homem (1999) esclarecem:

[O Rei] "foi chamado alma E coraçom de seu poboo ca assy como a alma jaz no coraçom do homem E per Ella ujue o corpo E se mantem assy elRey jaz E deue jazer de rrazom E direita justiça [...] E como o coraçom he huum E per ell Recebem todollos menbros unidade pera seer huum corpo E bem assy todollos do regno pero sejam mujtos porque elRey he huum [...] E em ell jaz deuem ser huus com ell dessy porque he cabeça do seu Regno" (ORDENAÇÕES DEL-REI DOM DUARTE, 1988: 310; HOMEM, 1999: 393).

A lei deve ser criada por meio da intermediação entre o legislador e o povo, para que seja justa. Nesse sentido, o poder de legislar é conferido ao soberano, embora a lei política seja subordinada à lei divina, esta pode ser representada pela referência corporal. Observa-se que o corpo físico se desenvolve através do embrião, submetido à cabeça. Assim, também é o reino que nasce do povo e se constitui como corpo místico, governado por um único homem que representa a sua cabeça. A vontade do povo tem função vital para o corpo político, assim como o coração garante a vida humana. 
O coração é o órgão vital do corpo humano, por irrigar sangue para todos os demais órgãos. A vontade do povo também representa a força vital para mover a cabeça do reino (o rei) e os outros membros (o concelho) que constituem o corpo político. Assim, a vontade do povo representa a união eficaz que exprime a vontade de Deus. Nesse sentido, o corpo humano toma forma para designar o corpo político: o coração é o representante da vontade do povo e desempenha a tarefa de irrigar a cabeça que ilumina o monarca; os nervos representam as leis e têm o ofício de ligar os membros aos órgãos, para que tenham vida (BALANDIER, 1997: 27).

A cabeça é fundamental nesse processo e, nesse caso, ela representa o rei, que é a cabeça do reino, comanda todo o corpo político e administra o reino. O sentido metafórico, de acordo com Balandier, não há totalidade na submissão das partes (povo) em relação ao conjunto (poder régio).

O objetivo de D. Afonso IV era firmar seu poder em relação à justiça do reino, colocando-se como cabeça e assumindo a postura de que o poder real provinha diretamente de Deus, sem intermédio da Igreja. Para tanto, utilizou do discurso de que o papa não deveria intervir nos assuntos temporais. Via a necessidade de delimitar a esfera de atuação do poder eclesiástico. Ao clero, portanto, caberiam somente as atividades ligadas à vida religiosa. Fernandes adverte que a justiça e as finanças compõem duas áreas livres da influência eclesiástica, uma vez que, várias áreas do reino concentravamse sob a tutela da Igreja, como a estrutura administrativa interna, por exemplo.

Homem (1999) cita uma lei estabelecida por D Afonso IV, sem datação registrada nas Ordenações del-Rey D. Duarte: “Todos aqueles que dereitamente entendem cuydar devem que o o rrey ou príncipe a que per deus rregimento He dado[...] rreconheçendo que o rregimento dos ditos rreinos que nos por deus He outorgad" (ORDENAÇÕES DEL-REY D. DUARTE, 1988: 466-467).

Esse período configurou-se como tempo de uma progressiva valorização da figura régia. Na teoria política adotada no medievo, o poder era concebido pela revelação divina assentada no projeto de Deus para os homens. Deste modo, a fonte documental informa que "Toda Ley he huma invençom, e dom de Deos, he ensinança de todollos sabedores, correção de todolos malfeitores volumptariosos com aspeito, e reguardamento comunal do Regno, ou Cidade [...]" (ORDENAÇÕES AFONSINAS, 1998: 5). De acordo com esta citação, as invenções devem, portanto, ser convertidas em leis positivas no reino de cada 
tempo. Assim, ocorre também com o pensamento divino relacionado à função do rei na ordenação provinda dos mandamentos divinos. Nessa expectativa, o monarca deveria estabelecer-se, sempre pautado pelos vários ramos da virtude, como o bem, a paz, a justiça, dentre outras.

A visão aristotélica, assim como a de Cícero e de Sêneca, constituídas na Antiguidade, baseava-se na virtude da justiça, com a qual o bom legislador deveria ser dotado. Portanto, as ações de um legislador/monarca deveriam ser conduzidas pelo belo agir. O que Aristóteles, na Política, denominou de nobreza, caracterizada no sentido de justiça (boas ações) dos atos humanos, para que se constituísse, dessa forma, uma cidade/reino como uma comunidade superior cujo fim último, é conquistar a autossuficiência e promover a vida boa (eu zen) à coletividade. Essa cidade, reino também deveria ser possuidora de um poder político que visasse libertar o indivíduo dos modos deficientes e incompletos de associação.

Apesar de D. Afonso III ter sido o responsável pelo início do processo de autonomia do poder régio em relação ao eclesiástico, essa só foi aprofundada com D. Afonso IV, pois este se instituiu simbolicamente como cabeça, coração e alma de seu reino. Das medidas tomadas por D. Afonso IV em relação às jurisdições civis e criminais, algumas atingiram mosteiros, que passaram a ser controlados por seus senhorios eclesiásticos, este foi o caso de Alcobaça. Outros, porém, continuaram a ser controlados em seus senhorios, como no caso de Arouca e Antuã, a Sé de Coimbra e em vários locais das Beiras, nos quais o monarca visava demarcar suas terras e separá-las dos bens da Igreja.

Quanto a esses privilégios, sabe-se que foram adquiridos em reinados anteriores, quando não havia legislação que os impedissem. Em muitos casos, foram sancionados pela realeza, portanto, contavam com a imunidade eclesiástica legítima e com poderes plenos. Em meio a tantas leis impeditivas, D. Afonso IV concedeu ao Mosteiro de Santa Clara (onde sua mãe D. Isabel ficou enclausurada desde a morte de seu pai em 1325, até morrer em 1336) o privilégio de herdar os bens de suas professas. Apesar de D. Afonso IV pretender apenas demarcar com precisão os coutos pertencentes ao clero e não retirar-lhes as terras, essa prática gerou contendas entre a coroa e a Igreja. Outro objetivo era o de garantir a cobrança dos direitos nos casos em que o clero detivesse bens pertencentes à coroa. No entanto, quando a pequena nobreza, composta por 
cavaleiros e escudeiros, invadia as terras da Igreja, buscando obter gêneros, o monarca normalmente colocava-se ao lado dos eclesiásticos.

Notamos que a atuação de D. Afonso IV em relação ao clero manteve-se seguindo duas vertentes: uma associada a uma política de demarcação de territórios, buscando definir o que era da coroa e os bens que pertenciam ao clero, e outra buscando definir o ofício do rei como juiz e legislador do reino, em todas as funções ligadas à administração e à legislação do território português.

\section{A Peste e seus efeitos no reinado de D. Afonso IV}

No medievo português, a alimentação era pobre e deficitária em vitaminas, feita à base de cereais, carne, peixe, vinho. Nesse cardápio, faltava vitamina D e parcelas consideráveis de A e C. A má alimentação, associada à pouca higienização, resultou para a sociedade medieval portuguesa em baixa resistência às infecções, fator que contribuía para a multiplicação das epidemias. Inúmeras epidemias ocorreram ao longo dos séculos XII, XIII e XIV. Nos anos correspondentes a 1190 e 1191, depois em 1233 e em seguida em 1333, a palavra "peste" ou "pestilência" tratava-se de uma designação comum a essa época. Contudo, Oliveira Marques, assinala que a verdadeira "peste" foi a bubônica, e que esta chegou à Europa em meados do século XIV. As epidemias anteriores difundidas entre a população, que causaram fome ou guerra, eram, na verdade, ocasionadas por disenterias e gripes pneumônicas, ou seja, doenças contagiosas. Desse modo, apresentavam características distintas. O aumento significativo da incidência dessas epidemias em meados do século XIV ocorreu por inúmeros motivos. Dentre eles, cita-se a pouca higiene nos hábitos cotidianos do medievo. Em Portugal, a "peste" de 1348 foi a maior delas (OLIVEIRA MARQUES, 1987: 93).

Destarte, observa-se que D. Afonso IV enfrentou um período conturbado, marcado pela crise econômica causada pelos efeitos devastadores da peste. $\mathrm{O}$ campo econômico também foi abalado por conta das inúmeras chuvas que prejudicaram a produção agrícola. A economia no medievo girava primordialmente em torno da agricultura e, para agravar ainda mais essa situação, houve a fuga de mão de obra do campo para as cidades, assim, faltou alimento em Portugal. Tal fuga gerou o abandono da terra e o acúmulo de mendigos nas cidades, pois esses trabalhadores dominavam as atividades ligadas à agricultura e ao se 
depararam com o trabalho nos centros urbanos, mostravam-se despreparados para tanto. Em relação ao reino português, sabe-se que a sangria demográfica provocada por essa epidemia, acirrou as contradições e os conflitos sociais entre empregadores e assoldados (BASTOS, 2009). A esse respeito, vale lembrar que D. Afonso IV deliberou uma lei sobre a carência da mão de obra, em 1349, pois a mão de obra no campo estava escassa, tanto pelo alto índice de mortalidade da população, quanto pela recusa dos agricultores em dar continuidade à execução destas atividades recebendo o mesmo valor de antes. A peste causou inúmeras consequências nos setores econômicos, morais e religiosos, conforme Wolff:

\footnotetext{
Um efeito lógico da peste foi a crise de mão de obra: de maneira incontestável, com a fuga completando a obra da morte, faltavam braços para o trabalho e tanto mais que, com a ameaça da morte tornando vão o entesouramento, muitos compradores apressaram-se em gozar a curta vida que, pensavam eles, restava para viver. Por toda parte tomaram medidas de precaução (WOLFF, 1988, p. 22).
}

Em Portugal a situação não foi diferente conforme vimos D. Afonso IV utilizou a legislação para regulamentar essa questão. Vale lembrar que a base da economia portuguesa medieval era quase totalmente baseada nas atividades agrícolas, e que há esse tempo faltou alimentos para sociedade. Deste modo, o apoio à guerra dado por $\mathrm{D}$. Afonso IV à Castela contra a invasão dos mouros, associado aos problemas causados pela peste contribuiu para que esse monarca aumentasse os impostos e, principalmente criasse novos impostos para os judeus. Outra medida tomada por esse rei para sanar parte dos problemas econômicos que afligiam seu reino nesse momento, confere a solicitação de D. Afonso IV ao papa Clemente VI (1342-1352), por meio de uma carta ${ }^{4}$ datada no ano de 1345, na qual pediu ao pontífice que lhe concedesse o direito de receber os dízimos da Igreja durante dois anos para amenizar as dificuldades que abalavam a economia do reino naquele período.

O desenvolvimento urbano das cidades atingiu seu apogeu no século XIII. A cidade modificou o homem medieval, restringindo seu círculo familiar, alargando as redes comunitárias nas quais ele participava e colocando o dinheiro no centro de suas preocupações materiais (LE GOFF, 1989: 19). As cidades atraíram homens de diversos 
grupos sociais e de origens distintas. Os mercadores, os homens do campo, a nobreza, os intelectuais das universidades, as ordens mendicantes, assim como pessoas desprovidas de trabalho, profissão ou qualquer meio de sobrevivência, convergiram para as cidades por considerá-las uma possibilidade de enriquecimento e uma forma de melhorar as condições de vida A cidade, nesse sentido, também se consolidou como um lugar no qual proliferavam os pobres, miseráveis ${ }^{5}$ e excluídos, a exemplo dos judeus, por serem estrangeiros (GEREMEK, 1995).

Quanto aos males causados pela peste, a maior incidência de mortes ocorreu no final de 1348, devastando Portugal. Há várias controvérsias quanto à origem dessa doença alguns defendem que tenha surgido no Mediterrâneo, outros, na China, ou, ainda, da Crimeia, trazida pelos genoveses, conforme salienta Esteves (2010). De acordo com Jeffrey Richards, dada a situação de escassez de alimentos, a qual se manteve ainda mais agravada pela epidemia, os judeus serviram de bodes expiatórios, como fonte de explicação para esse fenômeno inexplicável. Assim, foram acusados de conspirarem, junto a leprosos e muçulmanos, para o envenenamento dos poços e também de terem trazido a doença por meio de suas viagens a outras localidades (RICHARDS, 1993).

Na Idade Média as defesas imunitárias, bem como os conhecimentos científicos que pudessem contribuir para a cura da doença, ainda eram pouco desenvolvidos, careciam de mais estudos que indicassem suas causas, prevenções e as possibilidades de cura. A população contaminada morria ao abandono, ou seja, sem maiores cuidados, por conta da falta de assistência e de preparo no tratamento da peste. Há indícios de que, associada a essa enfermidade, várias outras epidemias tenham surgido nesse período. Por falta de conhecimento e também por criar reações parecidas com a da peste, todas eram tomadas como se fossem a "peste negra" ou bubônica. De acordo com Esteves, existiam evidências de que a contaminação advinha da mordida dos roedores ou da picada do arganaz (pulga xenopsylla chalopis). Após o contato, ocorria o surgimento do "bubão" (gânglio linfático hipertrofiado) na virilha ou nas axilas. O fato é que um terço da população portuguesa foi acometida pela doença, por causa da rapidez com que ela se propagou (ESTEVES, 2010: 46).

Quanto aos contextos que envolviam à Peste, pode-se observar que essa doença penetrava o (in)consciente coletivo da sociedade portuguesa medieval e moderna, 
seguindo por três vertentes discursivas sobre a sua procedência, que foram difundidas sob uma tríade de discursos proferidos, os quais sejam: a) Elaborado e disseminado a partir de uma perspectiva cristã; b) Baseado na ótica médica, pautadas na medicina de Hipócrates e Galeno; c) Regulado sob o ponto de vista régio (BASTOS, 2009).

As diretrizes cristãs do período, se orientavam a partir da matriz hipocráticogalênica herdada da Antiguidade e lhes eram fiéis na realização de práticas médicas contemporâneas a seu tempo. Consideravam o "envenenamento do ar" como causa natural e o identificavam como uma das principais causas da epidemia. Mas, em grau superior, submeteram as incidências desses surtos à vontade divina. Sob essa ótica, mesmo contando com situações naturais que favorecessem a eclosão da pestilência, ela só se manifestava por permissão de Deus. Neste sentido, atribuem a infecção causada por essa doença à uma função punitiva - como se fosse um castigo divino - em decorrência dos pecados cometidos pelos homens.

O discurso médico do período medieval e dos primórdios da "modernidade" portuguesa, também se encontravam atrelado a visão cristã. Embora, suas estratégias discursivas consigam se sobrepor aos princípios cristãos. Pois, percebe-se que o discurso médico difundido em Portugal no medievo, abarca aspectos relativos a "discriminação" social, voltada para grupos minoritários (ou pelo menos menorizados socialmente), como as prostitutas, os menos favorecidos economicamente e, àqueles de culturas diferenciadas.

Todavia, em casos de alastramentos epidêmicos recomendava-se à reclusão, até mesmo do próprio doente. Em tempos de Peste, o medo do contágio com a doença assolava toda sociedade do Ocidente medieval. Assumir a peste era um tabu no meio social. O isolamento nesses períodos era uma prática recorrente (DELUMEAU, 1989). O discurso médico, assim como o eclesiástico, se fundamentou na relevância social e na autoridade médica que o constituíram. Num víeis de cunho cristão, o médico se manteve comparado à natureza, pois nessa lógica, ambos são conduzidos pela diligência divina, a qual habilita este "ser" a agir adequadamente em defesa do estabelecimento e da preservação da saúde coletiva (BASTOS, 2009).

O discurso régio também segue a direção dos princípios cristãos, a priori estabelece um contraponto entre o mal, a doença e o pecado. Todos esses elementos são compreendidos como não "naturais", mas nada obsta que aceitem os princípios e as 
medidas estabelecidas pela medicina da época. Embora esta ação faça parte de um contexto político específico dos picos de centralização régia, em especial quando o governante necessita estabelecer certas medidas para conter ou minimizar as causas e os efeitos da pestilência. Os momentos de maior incidência das epidemias se compunham como os mais eficazes no desempenho das determinações régias.

Entretanto, a alocução régia se apropriou dos discursos: religiosos e médicos, os adaptando aos seus interesses e os revestindo de sua autoridade e poder. Buscando afirmação régia, mediante a demanda social contra o flagelo que assolava a Europa em tempos de surtos de peste (BASTOS, 2009). Por isso, pode-se reconhecer o poder do discurso como uma categoria conceitual que possibilita a análise do surgimento e das mudanças históricas dos sujeitos e dos objetos sociais. Como é sabido, o discurso por si só não esgota a realidade social que sustenta uma dada sociedade e não anula a possibilidade de utilização de outras categorias de análises. Assim, o discurso se constitui como um dos modos analíticos que podemos lançar mão para estudar as sociedades vigentes em determinado espaço e tempo. Seguindo esse fluxo epidêmico que periodicamente assolava Portugal, entre os anos de 1504 e 1507, a peste voltou a afligir os lusitanos, provocando muitas mortes. Deste modo, ao seu tempo D. Afonso IV, teve que fazer valer seu poder para minimizar os males ocasionados pela peste, assim como fizeram outros monarcas em tempos de seus governos.

A corte portuguesa valia-se de sua itinerância ${ }^{6}$ para deslocar-se de acordo com os indícios relativamente baixos de casos da doença nas cidades onde pretendessem permanecer por algum tempo, buscando fugir da epidemia. A doença não atingia as cidades ou vilas de forma homogênea e não ocorria em todos os lugares ao mesmo tempo. A corte régia se instalava nas cidades onde não havia casos da doença ou, onde esses casos fossem raros e isolados.

Entre os fatores que contribuíram para que essa epidemia assolasse Portugal, num curto espaço de tempo, pode estar também a fome gerada pela crise econômica, decorrência da má colheita. Desse modo, a população ficou ainda mais vulnerável à contrair a doença, proliferando, assim, o contágio. Nas cidades ou zonas onde havia maior concentração populacional e demográfica, a epidemia se alastrou com maior violência e rapidez. Já nos campos, onde havia menos pessoas e onde era mais isolado o índice de contágio, apresentou-se relativamente baixo, apesar de haver relatos de casos nos quais 
povoados inteiros ou algumas comunidades rurais tenham desaparecido. Em consequência, o contexto geral favoreceu o agravamento das divergências entre ricos e pobres. Esse cenário contribuiu para o surgimento de novos ricos, que fizeram fortuna com a herança recebida dos mortos na epidemia (ESTEVES, 2010: 45-46).

A Igreja também foi muito favorecida com o excessivo crescimento de seus bens, por ser ou se fazer herdeira de grande parte da população atingida pela contaminação da peste. Nessa época, a Igreja fortaleceu-se, pois os cristãos acreditavam que a epidemia era uma punição divina, contra os pecados cometidos. Principalmente os relacionados ao sexo entre fiéis e heréticos (como no caso dos judeus). Assim, a Igreja era vista pelos cristãos como a única instituição cujos sacerdotes eram capazes de ministrar missas e orações para apaziguar a "ira divina", à qual o povo atribuía a origem da doença e da crise econômica, esta última, provocada pela falta de trabalhadores no campo, pois muitos haviam morrido acometidos pela peste, visto que a agricultura era a base econômica desse período.

Com todo o poderio e fortalecimento conquistado pela Igreja, D. Afonso IV teve que atender a várias imposições do poder eclesiástico para se manter em harmonia com o clero. Levantamos a hipótese de que foi esse o motivo que levou o monarca a adotar uma política de restrição mais severa para com os judeus, fazendo com que se cumprisse a legislação de forma mais rigorosa, diferentemente da época de seu pai, D. Dinis.

Diante da devastação ocorrida, D. Afonso IV buscou minimizar o impacto das consequências da alta taxa de mortalidade: mediou as vilas/freguesias, de forma a orientar o procedimento jurídico quanto aos homens e as mulheres que após receberem heranças por falecimento de parentes próximos por conta da peste, não estivessem mais dispostos a trabalhar na agricultura ou nas atividades relativas a criação dos gados, ou àqueles que só aceitavam fazê-lo mediante ao recebimento de altos salários, valores estes que se sobrepunham às condições dos lavradores, os quais não o podiam pagar. Determinou que voltassem a trabalhar como antes, sem abusos e a realizar as atividades como lavrar, cuidar do gado, dentre outras, e que, mesmo se tivessem quantias em dinheiro ou cavalos, não se isentassem de trabalhar, pois essa falta de mão de obra estava causando perdas e danos à coroa e aos demais portugueses, conforme registrado na citação abaixo: ${ }^{7}$ 
[...] Sabede que a mjm he dicto que em essa vila e em seu termho ha homens e molheres que ante que deus desse a pestilência que hy ouve guaanhavam dinheiros per affam de seus corpos obrando cada huu e cada hua de seus mesteres e serviços e seruyam esses concelhos como conpria. E que agora que cobrarom alguus beens per mortes dalguas pessoas que sse teem em tan grandes que nom querem obrar de seus mesteres e servyços como ante faziam E que por esto os dessa vila e termho rrecebem grandes perdas e danos. E que outrossy ha hy outros muytos que ssoyan e servyr em cavar e em podar e em lavrar e em segar e em vendimhar e em guardar gaados e em fazer todolos outros servyços que a esse concelho conpria. E que agora nom querem servyr salvo se lhis derem quanto eles quyserem de guysa que os senhores das vinhas e erdades e gaados e doutras possissões [...] Tenho por bem e mando vos que em cada hua freyguesia desse logar ponhades dous homens boons dessa freguesia sem sospeita. Jurados aos sanctos avangelhos que bem e dereitamente sabham todos aqueles e aquelas que husavam de mesteres e servyam nos lavores das vinhas e erdades e gaados e das outras cousas [...] (LIVRO DAS LEIS E POSTURAS, 1978: 448-449, fl. 159, 1ª $2^{\mathrm{a}}$ col.).

Outra medida jurídica adotada por esse monarca, centrou-se na tentativa de reduzir o número de mendigos, que crescera em Portugal por conta da peste. Determinando que quando os lavradores tivessem qualquer tipo de atividade em suas terras, que os pedintes fossem trabalhar com eles e ficassem por lá pelo período de um ano de modo a receber os soldos pelos serviços prestados. A esse respeito, D. Afonso IV procedeu conforme o registro do Livro das Leis e Posturas, sobre os pedintes: ${ }^{8}$

[...] Neesto tenho por bem e mando vos que quando alguu lavrador ou algua outra pessoa ouver mester servydor por todo o ano e o achar e nom quyser entrar com El que o costrengades que more com el por huu ano e fazede lhj dar soldada aguysadamente pela guysa que dicto he. E porque esses servidores dizem que servem as soldadas e as nom podem aver daqueles a que as merecem. Tenho por bem que quando alguu servydor demandar perante vos alguu por algua soldada e achardes que de dereito tha deve dar mandade que ata três dias lha pague com as custas e perdas e danos que lhj por essa rrazom seguyrem. E sse a esse dia lha nom quyser pagar fazede lha pagar em dobro desse dia que lha ouver de dar a oyto dias [...] (LIVRO DAS LEIS E POSTURAS, 1978:. 451, fl. 159, $2^{\mathrm{a}}$ col.).

Essa determinação régia confluiu na tentativa e amenizar os problemas provenientes da mendicância. Deste modo, o monarca se dispôs a agir para que homens e mulheres que podiam realizar algumas atividades com os lavradores, e que mesmo 
assim continuavam pedindo nas portas e se recusavam a trabalhar, fossem constrangidos a fazê-lo. A esse respeito, ele ordenou que o concelho os obrigasse a cultivar os campos. E, se eles não quisessem cumprir a ordem e continuassem a praticar a mendicância, ${ }^{9}$ deveriam ser açoitados e colocados para fora das vilas e cidades. Os desocupados também não poderiam ser recebidos em albergarias ou hospitais e, se algum desses locais os acolhesse, seriam também punidas. A Igreja, em Portugal, seguiu tais medidas régias para conter a crise. $\mathrm{O}$ monarca exigiu daquela o pagamento das rendas, de acordo com os valores pagos pelos proprietários de quintas, campos e casas que doavam seus bens à Igreja.

As medidas adotadas por D. Afonso IV, para combater os excessos da Igreja em se apossar de grande parte das heranças e dos bens dos mortos, pautou-se na ordenança de que os procuradores e juízes régios, averiguarem a autenticidade dos testamentos, que por vezes eram forjados. Esse foi um dos meios jurídicos que D. Afonso IV, encontrou para minimizar o efeito devastador da mortalidade causada pela peste no reino e na Europa. Já sua atuação legislativa no caso de abandono dos campos quase que em massa pelos camponeses em 1349, retrata a gravidade e a rapidez dos efeitos devastadores da pandemia e da crise alimentícia instaurada nesse período. No entanto, a atuação política de D. Afonso IV apresentou-se de forma favorável ao reino português (ESTEVES, 2010: 47). Este monarca demonstrou-se atuante em detrimento aos problemas enfrentados em seu reinado, marcado por períodos de conflitos e querelas e, para além dele, assinalado por um contexto de pestilência, pela falta de mão de obra para desenvolver as atividades agrícolas, pela falta de alimentos que ocasionavam a fome e instabilidade do reino.

\section{A legislação afonsina quanto aos judeus no contexto de Peste}

Em períodos de surtos de pestes e epidemias, os judeus eram constantemente culpabilizados pelos flagelos que assolavam os reinos. Serviam como bodes expiatórios e nesses casos eram corriqueiramente acusados de disseminarem a doença pelo reino. A sociedade os acusavam de envenenarem os poços. Acreditavam que por possuírem cultura diferenciada eram capazes de cometer atos de blasfêmia maléficos à sociedade, os quais violavam os princípios básicos cristãos. Muitos judeus foram dizimados, em 
função de massacres, bem como difamados por conta dos rumores e das caricaturas que lhes eram impingidas, as quais normalmente os associavam a figura do diabo, um traidor.

As medidas legislativas mais severas de D. Afonso IV, quanto aos judeus se explica, pelo contexto conflituoso em que este rei esteve envolvido a partir de 1336, somando-se às consequências da Peste em Portugal, aspectos que deram a base favorável para que sua legislação fosse mais severa com os judeus e se adequasse às sansões do direito canônico, numa política diplomática com o pontificado romano por causa das dificuldades financeiras enfrentadas pelo reino, especialmente após 1340, o que favoreceu o aumento dos impostos aos judeus e também aos cristãos. Em vista disso, a política engendrada por monarca acerca dos judeus ocorreu, dentre outros fatores, por conta dos aspectos econômicos, políticos e religiosos que o reino vinha enfrentando a esse tempo.

O quadro se asseverou por meio de considerarem os judeus culpados pela peste, que havia assolado toda a Europa em 1348. Os cristãos, desde os tempos antigos, consideravam os judeus especialistas da magia - e no medievo a magia estava associada ao diabo. Obras de referência sobre bruxaria eram imputadas aos judeus na Idade Média (RICHARDS, 1993, p. 107).

No imaginário coletivo, feiticeiros de renome recebiam nomes judeus, como uma forma de transpor esse ritual ao judaísmo e associar a figura do diabo à magia, era uma maneira de associar os judeus ao satanismo. Os rituais da fé judaica eram vistos com maus olhos pela sociedade. Nesse sentido, podemos ressaltar a prática dos judeus de lavar as mãos sempre que voltavam de cemitérios, o ritual de jogar um punhado de terra atrás de si após o funeral a preparação para a Páscoa, que evidenciava a purificação dos fornos. Todas essas práticas eram interpretadas como magia. Suspeitavam até da inscrição bíblica que fixavam nas suas portas, a qual continha a palavra mezuzah. Por serem médicos, os judeus eram acusados frequentemente de envenenamentos. Houve ainda uma passagem em que a faculdade de medicina de Viena descreveu que os médicos judeus tinham um código privado que os obrigavam a assassinar um em cada dez pacientes atendidos (Richards, 1993, p.108).

Em 1246, o Concílio de Béziers proibiu os cristãos de serem atendidos por médicos judeus. Acreditava-se que era melhor morrer a dever a vida a um judeu. Essa 
medida acabou sendo ignorada ao longo dos séculos: muitos reis católicos foram atendidos por médicos judeus, como no caso de D. Duarte (1433-1438).

Pode-se associar a proteção dos pontífices aos judeus, à tolerância evidenciada por Santo Agostinho. Nessa expectativa, os judeus deveriam ser tolerados, pois a Igreja Católica romana objetivava adquirir mais adeptos. Os judeus, portanto, deveriam ser convertidos à fé cristã. Por vezes, o papado impôs que os judeus não deveriam ser perseguidos por conta da religião e que suas sinagogas ${ }^{10}$ também não poderiam ser pilhadas ou destruídas. Esses ataques e a crueldade a que os judeus foram expostos desde o final do século XI criaram a ideologia, a partir do século posterior, de que os judeus eram pertencentes aos monarcas cristãos, onde eles vivessem. Nesse sentido, cartas que definiam os direitos e deveres desse grupo foram prescritas para que os reis concedessem a eles proteção. Mas, em troca de tal proteção, pagariam altos tributos à coroa.

Contudo, D. Afonso IV, os obrigou a usar o sinal de distinção costurado as vestes à altura do peito - Estrela de Davi -, que os distinguia dos cristãos, os impelindo a pagarem tributos mais altos que os cristãos, em todas as atividades que desenvolviam nesse período, de compra, venda e outras transações. O fato, é que este monarca se viu mediante um período delicado para gerir e buscou lançar normas para o bom andamento do reino, mesclando seus interesses aos interesses da coroa.

\section{Considerações finais}

D. Afonso IV, a exemplo de outros reis do medievo buscou fortalecer o poder régio em detrimento ao poder eclesiástico, recorrendo a diversos tipos de subterfúgios e estratégias governamentais para fortalecer o poder jurídico da coroa, criando leis e investindo na criação de cadeiras e disciplinas na Universidade dando vasão aos estudos jurídicos, como um meio de fortalecer o poder régio. Um modo de contornar as querelas, os conflitos, as doenças e a fome em seu governo este monarca atentou-se principalmente para a legislação em seu período. Lembrando que a peste estava associada à altíssima taxa de mortalidade, proveniente do alastramento dessa doença que se tornou promotora de uma ampla devastação demográfica na sociedade europeia 
nesses períodos epidêmicos. A este fator, somava-se o crescente sentimento antijudaico desenvolvido pela sociedade desfavorecida de recursos financeiros. Pois em tempos de peste, esse grupo desprovido de recursos econômicos relevantes ficavam desassistidos de ações sociais que os protegessem e, acabavam pagando as contas de terem que permanecer onde viviam mesmo sob o julgo de terem que conviver em lugares de elevados fluxos de pessoas e, com maior probabilidade de terem que enfrentar o surto da doença. Enquanto a nobreza e a corte nesses períodos se refugiavam no campo, longe das aglomerações, atendendo as instruções médicas de se afastarem dos espaços mais habitados e de maior fluxo de pessoas. Assim, como resposta a essa (des)assistência da Coroa, esse grupo desfavorecido acabava elegendo os judeus (cristãos-novos) como seus inimigos e possibilitadores dessa epidemia, em virtude de sua mobilidade espacial.

O afastamento dos centros e o distanciamento social é uma ação notável mesmo no medievo, pois em períodos de surtos da Peste em que era impossível ignorá-la, as famílias mais abastadas fugiam das cidades ou vilas, se refugiam em locais menos povoados, de preferência no campo. Aqueles que ficavam no meio urbano também buscavam o isolamento. As autoridades laicas e religiosas aspergiam as moedas e as missivas com vinagre, usavam uma máscara com um bico de pássaro com perfumes. A doença causava desestruturação no meio citadino e nas famílias também, os comerciantes tratavam de seus negócios mantendo distância de seus compradores; os padres ofereciam sacramentos à distância, na ponta de uma vara e os relacionamentos entre os vizinhos eram cessados. (DELUMEAU, 1989: 171-176). Diversas eram as tentativas em se afastarem das doenças contagiosas. Quanto a administração da coroa, essa seguia um padrão semelhante em que D. Afonso IV empreendeu um poder diligente quanto as causas legislativas que estavam a cargo da coroa e das quais dependiam a sua administração para que o reino não sofresse com tanta ênfase as mazelas. Assim, buscou para minimizar as condições adversas que teve que enfrentar durante seu governo, fossem elas de cunho político, econômico, das relações de poder ou pelas doenças epidêmicas em percurso nesse período. 


\section{Referências}

ARISTÓTELES. Política. Edição bilíngue (português-grego) com tradução directa do grego. Trad. António Campelo Amaral e Carlos de Carvalho Gomes. $1^{\mathrm{a}}$ ed. Lisboa: Vega, 1998.

BALANDIER, Georges. O contorno: poder e modernidade. Rio de Janeiro: Bertrand Brasil, 1997.

O poder em cena. Trad. Luiz Tupy Caldas de Moura. Brasília: Editora Universidade de Brasília, 1982.

BASTOS, Mário Jorge da Motta. O poder nos tempos da peste (Portugal séculos XIV/XVI). Niterói: Ed. UFF, 2009.

COELHO, Maria Helena da Cruz. O poder e a sociedade ao tempo de D. Afonso $I V$. In: Revista de História. Porto, p. 35-51, v. 8, 1988.

DELUMEAU. Jean. História do medo no Ocidente 1300-1800. São Paulo: Companhia das Letras, 1989.

ESPÍRITO SANTO, Moisés do. Origens da Religião Portuguesa. Lisboa: Assírio \& Alvim, 1988.

ESTEVES, Julieta Araújo. "D. Afonso IV, O Bravo (1325-1357)". In: MENDONÇA, Manuela. História dos reis de Portugal: Da fundação à perda da independência. Lisboa: Academia Portuguesa da História/Ed. Quidinovi, 2010.

FERNANDES, Fátima Regina. A recepção do Direito romano no Ocidente europeu medieval: Portugal, um caso de afirmação régia. In: Revista História: Questões e Debates. Curitiba, no 41, p.73-83, 2004.

FONSECA, Faustino da. A carta de Afonso IV ao papa Clemente VI. In: BIBLIOTECAS E ARQUIVOS DE PORTUGAL, Anais... Lisboa, v. 2, p. 67-68. Obra digitalizada pela Biblioteca Nacional Digital de Portugal. Disponível em: $<$ http://purl.pt/255/2/P299.html>. Acesso em jul. 2008.

GEREMEK, Bronislaw. Os filhos de Caim. Vagabundos e miseráveis e a literatura européia 1400-1700. São Paulo: Cia das Letras, 1995. 
GIMENEZ, José Carlos. A rainha Isabel nas estratégias políticas da Península Ibérica: 1280-1336. 2005. 211f. Tese (Doutorado) Faculdade de Ciências Humanas, Letras e Artes. Universidade Federal do Paraná, Curitiba, 2005.

GOMES, Rita Costa. As formas de vida: A corte e o Espaço. In: A Corte dos reis de Portugal no final da Idade Média. Viseu: Difel, 1995.

HOMEM Armando Luís Gomes de Carvalho. O desembargo régio (1985-1990); (1320-1433). 2 vols. Porto: INIC / CHUP, 1985.

HOMEM, Armando Luís de Carvalho. Rei e "estado real" nos textos legislativos da Idade Média portuguesa. In: Revista En la España Medieval. n ${ }^{\circ}$ 22, p. 177-185, 1999.

JESUS. Fr. Rafael de O.S.B. Monarquia Lusitana. Portugal: Ed. Imprensa Nacional Casa da Moeda, 1980/2008, v. VII.

LE GOFF, Jacques. O homem medieval. Lisboa: Ed. Presença, 1989.

LIVRO DAS LEIS E POSTURAS. Transcrição paleográfica de Maria Teresa C. Rodrigues. Lisboa: Faculdade de Direito da Universidade de Lisboa, 1971.

OLIVEIRA MARQUES, Antônio Henrique de. Portugal na crise dos séculos XIV e XV. Lisboa: Editorial Presença, 1987.

ORDENAÇÕES AFONSINAS. Lisboa: Fundação Calouste Gulbenkian, 1984. Livro 1-2.

ORDENAÇÕES Del-Rei Dom Duarte. Lisboa: Fundação Calouste Gulbenkian, 1988.

RICHARDS, Jeffrey. Sexo, desvio e danação. As minorias na Idade Média. Rio de Janeiro. Zahar. 1993.

\section{Notas}

\footnotetext{
${ }^{1}$ Este artigo resulta de uma reelaboração e aprofundamento das ideias desenvolvidas inicialmente na minha Dissertação de Mestrado apresentada e defendida na Faculdade de História da Universidade Federal de Goiás - UFG, em 2012.

2 Essa rainha desempenhou papel social e político de grande relevância em Portugal, José Carlos Gimenez, em sua tese A rainha Isabel nas estratégias políticas da Península Ibérica: 1280-1336, salienta
} 
que ela resignou-se diante das aventuras extraconjugais de D. Dinis, acolhendo de modo afetuoso os filhos bastardos do monarca. Realizou atos de benevolência, buscando favorecer os pobres, e empenhouse no trabalho filantrópico da construção de albergues e de hospitais para leigos e religiosos. Também interveio de forma providencial na tentativa de estabelecer acordos nas divergências internas do reino, bem como, nas conturbadas e delicadas relações políticas nos reinos ibéricos. (GIMENEZ, 2005: 02).

${ }^{3}$ Há controvérsias quanto à oficialidade da canonização da Rainha Isabel, o sociólogo Moisés do Espírito Espírito Santo (1988) salienta que embora Urbano VIII tenha decretado a canonização por meio de uma bula pontifícia, o certo é que, nem no pontificado dele, nem dos onze papas que o sucederam o documento não foi lavrado. Apesar de Urbano VIII (1623-1644) ter recebido os créditos por ter canonizado a rainha, o cerimonial que este realizou foi de fachada, pois, não foi registrado em ata. $\mathrm{O}$ autor esclarece que este papa iludiu a sociedade portuguesa deste período, visto que, foi o papa Bento XIV (1740-1758) que já no século XVIII registrou o solene diploma. Mas, ainda assim, verifica-se inexatidão na bula, numa parte a canonização registra o dia 24 de junho de 1626, enquanto noutra aponta que esta se deu em 1625 (ESPÍRITO SANTO, 1988:192).

${ }^{4}$ Conforme afirma Fonseca utilizando como respaldo a carta de D. Afonso IV ao papa Clemente VI "[...] Acaso, ó Pai espiritual, não exposemos, há pouco a V. Santidade por intermédio dos nossos embaixadores as nossas necessidades, que pela defesa e dilatação da fé cathólica havemos contraído, e em razão das quaes vos temos suplicado Beatíssimo Padre que vos digneis auxiliar-nos, concedendo-nos com paternal piedade o dízimo das egrejas dos nossos reinos? Quem acusará um rei de pedir quando carece? Nisto porém V. S. ${ }^{\text {de }}$ nos descupará. A gente de guerra e os nossos navios, ainda que os tivessemos em maior quantidade, não podemos distrahi-los, e envia-lo sem auxilio dos outros, por causa da guerra que sustentamos contra e nos propomos sustentar com os agarerenos nossos visinhosperfidos e poderosos [...]". FONSECA. Disponível em: <http://purl.pt/255/2/P299.html>. Acesso em jul. 2008.

5 A origem do fenômeno miséria é bastante complexa e apresenta várias interpretações. A imagem do pobre muda de acordo com a época estabelecida para a pesquisa (GEREMEK, 1995: 07).

${ }^{6}$ A corte peregrinava por todo o reino buscando fortalecer o poder régio e, no centro dessa itinerância, estava a figura do monarca (GOMES, 1995: 279).

${ }^{7}$ Lei que constregam os homees que husem de seu mester e que morem por soldada os que fforem pera ela (LIVRO DAS LEIS E POSTURAS, 1978: 448-449, fl. 159; $1^{\text {a }}, 2^{\mathrm{a}}$ col.).

8 Lei: Dos que andam pidindo, para mais informações conferir no LIVRO DAS LEIS E POSTURAS, 1978: 450-451, fl. 159v., $1^{\text {a }}, 2^{\mathrm{a}} \mathrm{col}$.

${ }^{9}$ Todos que fossem encontrados sem profissão como vadios, pedintes, falsos doentes, dentre outros, deveriam se dedicar à urgente tarefa de cultivar os campos e ao concelho foi determinado ainda que se fizesse o tabelamento dos salários (COELHO, 1988: 48).

${ }^{10}$ Local de culto da religião judaica, a qual tem como seu objeto central a Arca da Torá. Nesse espaço, reúnem-se fiéis diariamente, para fazerem o estudo da Torá. 